How to cite: Lupu, I., Perju, R., Moldoveanu, M. (2020) A Method to Collect Field Data for Hydromorphological Monitoring of Rivers in Romania. 2020 "Air and Water - Components of the Environment" Conference Proceedings, Cluj-Napoca, Romania, p. 135-146, DOI: 10.24193/AWC2020_13.

\title{
A METHOD TO COLLECT FIELD DATA FOR HYDROMORPHOLOGICAL MONITORING OF RIVERS IN ROMANIA
}

\author{
Iulia LUPU ${ }^{1,2}$, Ruth PERJU ${ }^{2}$, Marinela MOLDOVEANU ${ }^{2}$
}

DOI: 10.24193/AWC2020_13

\begin{abstract}
The monitoring of rivers' hydromorphological characteristics represents a requirement of the EU Water Framework Directive 2000/60/EC (WFD) amended in $2014(2014 / 101 / \mathrm{EU})$, which introduces several standards regarding the monitoring of the quality elements of all surface water categories. Thereby, for the hydromorphological elements, the Standard 14614:2004 Water quality - Guidance standard for assessing the hydromorphological features of rivers became mandatory. In this view, a method for field data collection was developed considering the specifications of the mentioned Standard. The method, focused on surface water bodies - rivers, is based on both field surveys and desk work, the information being registered in two types of records (A and B). The hydromorphological monitoring is to be conducted on survey units (SU) of fixed length $(500 \mathrm{~m})$ and variable widths, with detailed observations and measurements in three sections: upstream and downstream (at SU' boundaries) and a base section (approx. at the middle of the SU). The field measurements are supplemented by visual observations and estimation of some hydrological and morphological characteristics. At the same time, if on field measurements and samplings are not possible,the method permits the collection of data only from visual observations and estimations. Given the fact that the Methodology for hydromorphological assessement of Romanian rivers, which is included in the second Romanian River Basin Management Plan 2016-2021 (RBMP), considers the indicators for three main categories of hydromorphological elements: hydrological regime, river continuity and morphological conditions and that the proposed method for data collection follows the specifications of the same documents (WFD, RBMP etc.), we consider the method provides good support in desk resulted data validation and completion, for both, monitored rivers (through gauging stations) and unmonitored rivers.
\end{abstract}

Keywords. rivers, hydromorphology, monitoring, field survey, survey unit, Water Framework Directive (WFD)

\section{INTRODUCTION}

Monitoring water quality parameters is a complex activity, essential for the management of aquatic ecosystems at local or national level decision making. According to the European legislation, the Member States should develop an

\footnotetext{
${ }^{1}$ University of Bucharest, Faculty of Geography, Doctoral School of Geography „Simion Mehedinți”

${ }^{2}$ National Institute of Hydrology and Water Management
} 
integrated surface water quality monitoring system by using three categories of water quality elements: biological, hydromorphological and physico-chemical.

The methods for monitoring and evaluation of rivers' hydromorphological characteristics should be developed in accordance with the requirements of the Water Framework Directive 2000/60/CE (WFD), amended in 2014 with the standards SR EN 14614/2004 and EN 15843/2010. These standards, elaborated by the European Comittee for Standardization (Ilnicki et al., 2010), reffer to the monitoring of the quality elements for all types of surface waters and their specifications are compulsory for all Member States.

Regarding the existing monitoring and assessment methods, a first analysis was made by Birk (2003) through the STAR project (Standardisation of River Classification - Framework Method for Calibrating different Biological Survey Results against Ecological Quality Classification to be developed for the Water Framework Directive), in which 23 methodes were identified and analysed.

A more recent analysis of the monitoring and assessment methods of rvers' hydromorphological characteristics was conducted in the European project REFORM (Restoring Rivers for Effective Catchment Management), finished in October 2015 (Wolter et al., 2013, Gurnell et al., 2016). The project considered 139 methods, of which 73 european and 66 non-european and focuses on highliting the methods' features: their reference conditions, the parameters/characteristics considered and recorded, the processes in the riverbed and their application in the context of WFD implementation (namely if a method is the official tool or it is frequently used, but not compulsory in the state that developed it).

Given the fact that the implementation of the WFD was in initial state at the time of STAR project, just three of the methods analysed within STAR project are found in the European project REFORM.

The results of REFORM project show that the main limitations of the methods are: (i) none of the methods includes the monitoring of all the characteristics/attributes required by the Standard EN 14614:2004; (ii) the monitoring is conducted on representative river reaches with fixed or variable dimentions, not at water body level; (iii) the morphological features/processes are, in general, insufficiently analyzed.

Romania has a long tradition in hydromorphological monitoring of rivers, especially through the hydrometric activity conducted at gauging stations, where the data collected/recorded over the years led to a historical database. An assessment method based especially on data from gauging stations has been developed in 2015, applied and adopted as the unique tool for hydromorphological assessment at national level (INHGA, 2015; Moldoveanu et al., 2015), through the updated National Management Plan 2016-2021 (ANAR, 2016).

However, the correlation of the monitoring activity at the gauging stations with the WFD and recent standards requirements became a necessity in the last years. Therefore, the present paper presents a method to collect field data for hydromorphological monitoring of rivers, adapted to the posibilities and conditions of our country (INHGA, 2016). 


\section{DATA AND METHODS}

The method takes into account the Water Framework Directive requirements in terms of hydromorphological status assessment (hydrological regime, river continuity and morphological conditions) and the specifications of the international standards (SR EN 14614/2004 and EN 15843/2010) regarding how the field observations (the scale) should be made and what features should be recorded. Therefore, the method considers the hydromorfological features of the river channel, banks and riparian zone, including floodplain.

Regarding the scale of surveys the method uses "survey units" of fixed lenght and variable width. The deliniation (location and dimension) of the survey units within the river water bodies have been presented in detail in Lupu et al. (2017).

The categories and features used for hydromorphological monitoring of Romanian rivers according to the proposed method are presented in Table 1.

Table 1. Categories and features for hydromorfological monitoring of Romanian rivers $(\mathrm{O}=$ Office, $\mathrm{F}=$ Field; $\mathrm{WB}=$ water body, $\mathrm{SU}=$ survey unit

\begin{tabular}{|c|c|c|c|c|}
\hline No. & Categories and features & Specification on collecting the data & \begin{tabular}{|l|} 
Work \\
stage
\end{tabular} & $\begin{array}{l}\text { Spatial } \\
\text { scale }\end{array}$ \\
\hline 0 & 1 & 2 & 3 & 4 \\
\hline \multicolumn{5}{|c|}{ CHANNEL } \\
\hline \multirow[t]{3}{*}{1} & Channel form & - & $\begin{array}{l}\mathrm{O} \\
\mathrm{F}\end{array}$ & $\begin{array}{l}\text { WB } \\
\text { SU }\end{array}$ \\
\hline & Long section profiles & $\begin{array}{l}3 \text { points }+ \text { additional points for } \\
\text { special conditions }\end{array}$ & $\begin{array}{l}\mathrm{O} \\
\mathrm{F}\end{array}$ & SU \\
\hline & Cross profiles & At least 3 cross sections & $\begin{array}{l}\mathrm{O} \\
\mathrm{F}\end{array}$ & SU \\
\hline \multirow[t]{2}{*}{2} & $\begin{array}{l}\text { Observations on the material making up } \\
\text { the river bed }\end{array}$ & $\begin{array}{l}\text { Type and condition of material of } \\
\text { river bed }\end{array}$ & $\mathrm{F}$ & SU \\
\hline & Observations on alluvial materials & $\begin{array}{l}\text { Samples from river bed, particle-size } \\
\text { distribution curves }\end{array}$ & $\mathrm{F}$ & SU \\
\hline \multirow[t]{3}{*}{3} & $\begin{array}{l}\text { Observations on existing aquatic } \\
\text { macrophytes and their development }\end{array}$ & $\begin{array}{l}\text { Information from monitoring activity } \\
\text { + additional activity where } \\
\text { applicable }\end{array}$ & $\mathrm{F}$ & SU \\
\hline & $\begin{array}{l}\text { Observation on existing of leafy and } \\
\text { woody debris }\end{array}$ & - & $\mathrm{F}$ & SU \\
\hline & $\begin{array}{l}\text { Observations on existing vegetation } \\
\text { management activity }\end{array}$ & - & F & SU \\
\hline 4 & $\begin{array}{l}\text { Observations on the evolution of channel } \\
\text { and banks regarding erosion/deposition } \\
\text { of alluvial material }\end{array}$ & $\begin{array}{l}\text { Cross sections' comparative analyses } \\
\text { (over time) }\end{array}$ & $\begin{array}{l}\mathrm{F} \\
\mathrm{O}\end{array}$ & SU \\
\hline \multirow[t]{3}{*}{5} & Observations on flow type & - & F & SU \\
\hline & Observations on flow features & - & F & SU \\
\hline & $\begin{array}{l}\text { Inventory of water uses at water body } \\
\text { level } \\
\text { Annual average flow } \\
\text { extracted/introduced in the water body }\end{array}$ & $\begin{array}{l}\text { Type of water usage } \\
\text { Analogy with annual average } \\
\text { discharge in natural flow conditions }\end{array}$ & $\begin{array}{l}\mathrm{O} \\
\mathrm{F}\end{array}$ & $\begin{array}{l}\text { WB } \\
\text { SU }\end{array}$ \\
\hline
\end{tabular}




\begin{tabular}{|c|c|c|c|c|}
\hline No. & Categories and features & Specification on collecting the data & \begin{tabular}{|l|}
$\begin{array}{l}\text { Work } \\
\text { stage }\end{array}$ \\
\end{tabular} & $\begin{array}{l}\text { Spatial } \\
\text { scale }\end{array}$ \\
\hline 6 & $\begin{array}{l}\text { Inventory of artificial barriers } \\
\text { Location of obstacles on the longitudinal } \\
\text { profile }\end{array}$ & - & $\begin{array}{l}\mathrm{O} \\
\mathrm{F}\end{array}$ & $\begin{array}{l}\text { WB } \\
\text { SU }\end{array}$ \\
\hline \multicolumn{5}{|c|}{ BANK } \\
\hline \multirow[t]{2}{*}{7} & Observations on bank material types & $\begin{array}{l}\text { Material type estimation and } \\
\text { particle-size distribution curves (at } \\
\text { least in } 3 \text { points at cross section } \\
\text { profiles) }\end{array}$ & $\mathrm{F}$ & SU \\
\hline & $\begin{array}{l}\text { Observations on revetment or protection } \\
\text { material }\end{array}$ & $\begin{array}{l}\text { Specifications on type and condition } \\
\text { of water works (e.g.: good condition, } \\
\text { bad condition) }\end{array}$ & $\begin{array}{l}\mathrm{O} \\
\mathrm{F}\end{array}$ & $\begin{array}{l}\text { WB } \\
\text { SU }\end{array}$ \\
\hline \multirow[t]{2}{*}{8} & Observations on vegetation types & $\begin{array}{l}\text { Information from monitoring activity } \\
\text { + additional activity where } \\
\text { applicable }\end{array}$ & F & SU \\
\hline & $\begin{array}{l}\text { Observations on vegetation condition at } \\
\text { field survey moment }\end{array}$ & - & F & SU \\
\hline \multicolumn{5}{|c|}{ RIPARIAN ZONE (FLOODPLAIN) } \\
\hline \multirow[t]{2}{*}{9} & $\begin{array}{l}\text { The share of the three main categories of } \\
\text { land cover, according to Corine Land } \\
\text { Cover methodology recognition of } \\
\text { vegetation types and human activities } \\
\text { causing vegetation discontinuity }\end{array}$ & $\begin{array}{l}\text { According to the Methodology for } \\
\text { hydromorphological assessment of } \\
\text { rivers, (ANAR, 2015 - Annex } \\
\text { 6.1.2.A) }\end{array}$ & $\begin{array}{l}\mathrm{O} \\
\mathrm{F}\end{array}$ & $\begin{array}{l}\text { WB } \\
\text { SU }\end{array}$ \\
\hline & $\begin{array}{l}\text { Observations on riparian floodplain } \\
\text { morphology (anthropogenic changes) }\end{array}$ & $\begin{array}{l}\text { Description of river meadow (shape) } \\
\text { and of the existing changes (polder, } \\
\text { fish ponds, irrigation channels) }\end{array}$ & $\begin{array}{l}\mathrm{O} \\
\mathrm{F}\end{array}$ & $\begin{array}{l}\text { WB } \\
\text { SU }\end{array}$ \\
\hline 10 & $\begin{array}{l}\text { Inventory of water works } \\
\text { Dikes length and height; distance from } \\
\text { the dikes to the river channel }\end{array}$ & - & $\begin{array}{l}\mathrm{O} \\
\mathrm{F}\end{array}$ & $\begin{array}{l}\text { WB } \\
\text { SU }\end{array}$ \\
\hline
\end{tabular}

The hydromorfological categories and features listed above are the subject of the two field survey forms used to collect and record the results of the field measuremets and observations, inluding new anthropogenic pressures identified.

\section{RESULTS AND DISCUSSIONS}

The monitoring method for river hydromorphological parameters/characteristics proposes the selection and establishment of survey units (US) with a fixed length of $500 \mathrm{~m}$ and a variable width, depending on the width of the riparian (floodable) zone, estimated on field. The field forms elaborated follow the requirements and recomandations of SR EN 14614/2004 standard and includes the three zones of the river: the minor riverbed, the banks and the riparian zone (floodplain).

In order to record and highlight the hydromorphologic features of the river, three sections are selected within the survey unit: upstream section, downstream section and base section, observations and measurements being recorded for each of them. They are located at the limits of the suvey units (the upstream and downstream sections) and approx. at the middle of the suvey unit (base section). 
The process of montoring the hydrological and morphological parameters/characteristics is carried out in three steps: planning the fieldwork, the field step (field campaign) and the data post-processing step (fig. 1).

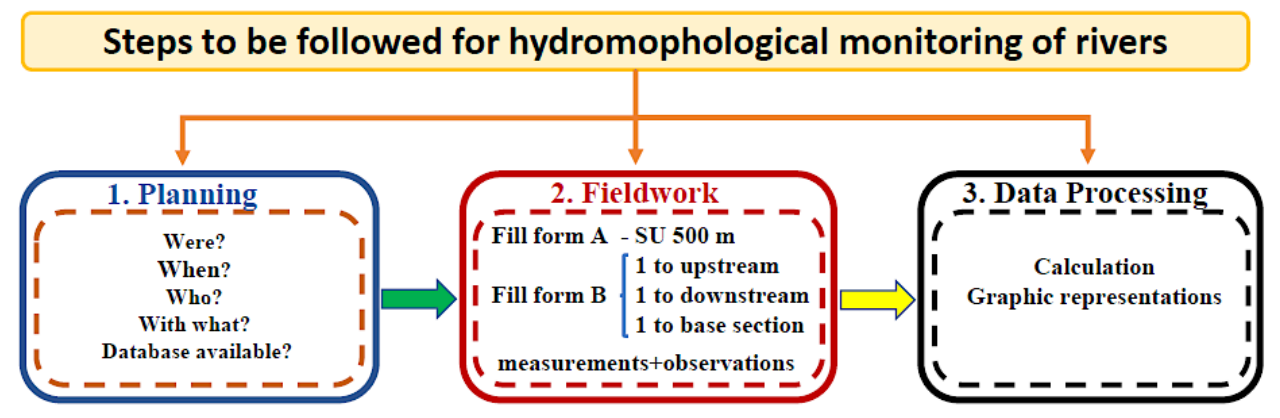

Fig. 1. Schematic representation of steps and main activities for hydromorphological monitoring of rivers

\subsection{Planning the fieldwork}

In the planning step of the monitoring process, activities which are the basis for the preparation of the field campaign are conducted, as follows:

- the responsible with the activity is established;

- the team that will carry out the field campaign is established, with at least 2 people from different fields of research (hydrologists, geologists, geodesists, biologists etc.);

- the survey units and survey sections are selected/delimited and marked on maps;

- the team identifies the equipments necessary to fulfill the field campaign and the measurements required (topographic equipments, protective and work equipments, hydrological measurement equipments, recipients and sampling equipments, forms/questionnaires for recording data from observations, standard field forms for hydrological measurements etc.);

- depending on the available equipments, the actual work methods are established (measurements/determination of parameters, direct or indirect identification of the characteristics/parameters);

- the existing data/information is collected, analysed and recorded in the forms/questionnaires for the survey units, namely for the surface water bodies.

The collection and analysis of the existing data and information is an important step preceding the field campaign, because it reduces the time for the actual on-field activity (some characteristics being defined beforehand).

In this regard, the data/information can be obtained form the databeses available (thematic maps, aerial images, digitized and raster files processed in GIS environment). The data collected in this stage are used for the efficient coordination and development of the field campaign. 


\subsection{Field campaign}

This step implies the on-field campaign, where the team fills out the forms type A and B (Fig. 2a and b, Fig. 3a and b) according to the measurements and/or the visual observations on hydrological and morphological parameters/characteristics. Topographic measurements regarding the cross sections, as well as discharge measurements and alluvia sampling are made, if the technical and field conditions allow it.

The type A form refers to Observations and measurements for hydromorpological monitoring of the surface water bodies - rivers through survey units and contains information for the suvey unit on the whole $(500 \mathrm{~m})$.

The type $\mathrm{B}$ form refers to Observations and measurements for hydromorpological monitoring of the surface water bodies - rivers through survey units and contains information for each of the three sections within the survey unit: upstream, downstream and base sections (one form for each section).

Both types of forms have the same structure, namely: general information (about the water body, survey unit and sections); aspect, alluvia and vegetation in the minor riverbed; aspect and structure of the bank and of the riparian zone, but with a different degree of detail of the observations to be made.

\subsection{Post-processing of the field obtained data}

The post-processing of the data mainly refers to discharge measurements calculation, calculation and graphical representation of the cross sections, alluvia samples processing and representation of the resulting particle size curves. The data obtained are filled in the forms type A and B.

\section{CONCLUSIONS}

The process of water quality monitoring implies the periodic update of the information on water quality status. This fact entails the necessity of reconsidering and adapting the hydrometric program on rivers, taking into account the current possibilities and the monitoring methods implemented at national level.

Due to its novelty elements (survey units including or not survey sections overlaping monitoring sites from the national hydrometric nework, structured forms with well delimited parts, for each main element defined in the WFD and standards, recording data on biological aspects etc.), the presented method supports the integrated monitoring of river water bodies, being an usefull tool in WFD implementation in Romania.

The presented method, tested on river water bodies from all typologies, provides good support in desk resulted data for both, monitored rivers (through gauging stations) and unmonitored rivers, for the purpose of water quality assessement.

Data collection for all quality elements that define the ecological status of rivers (the chemical, the biological and the hydromorphological elements), in the same place and at the same time is useful and necessary to create an integrated database. 


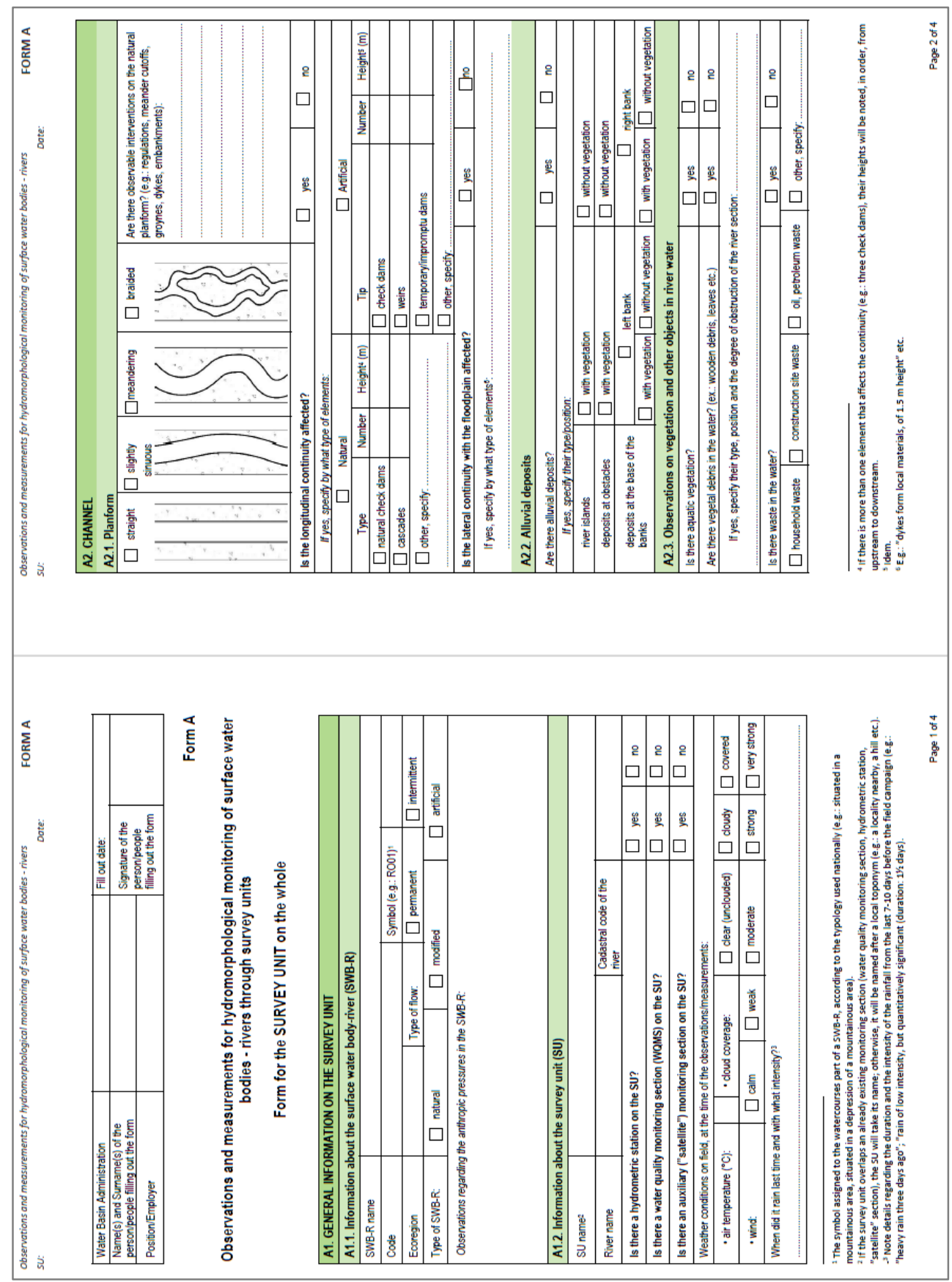

Fig. 2a. Form type A - Observations and measurements for hydromorpological monitoring of the surface water bodies - rivers through survey units, which refers to data collection on the survey unit on the whole - $500 \mathrm{~m}$ (pages 1-2) 


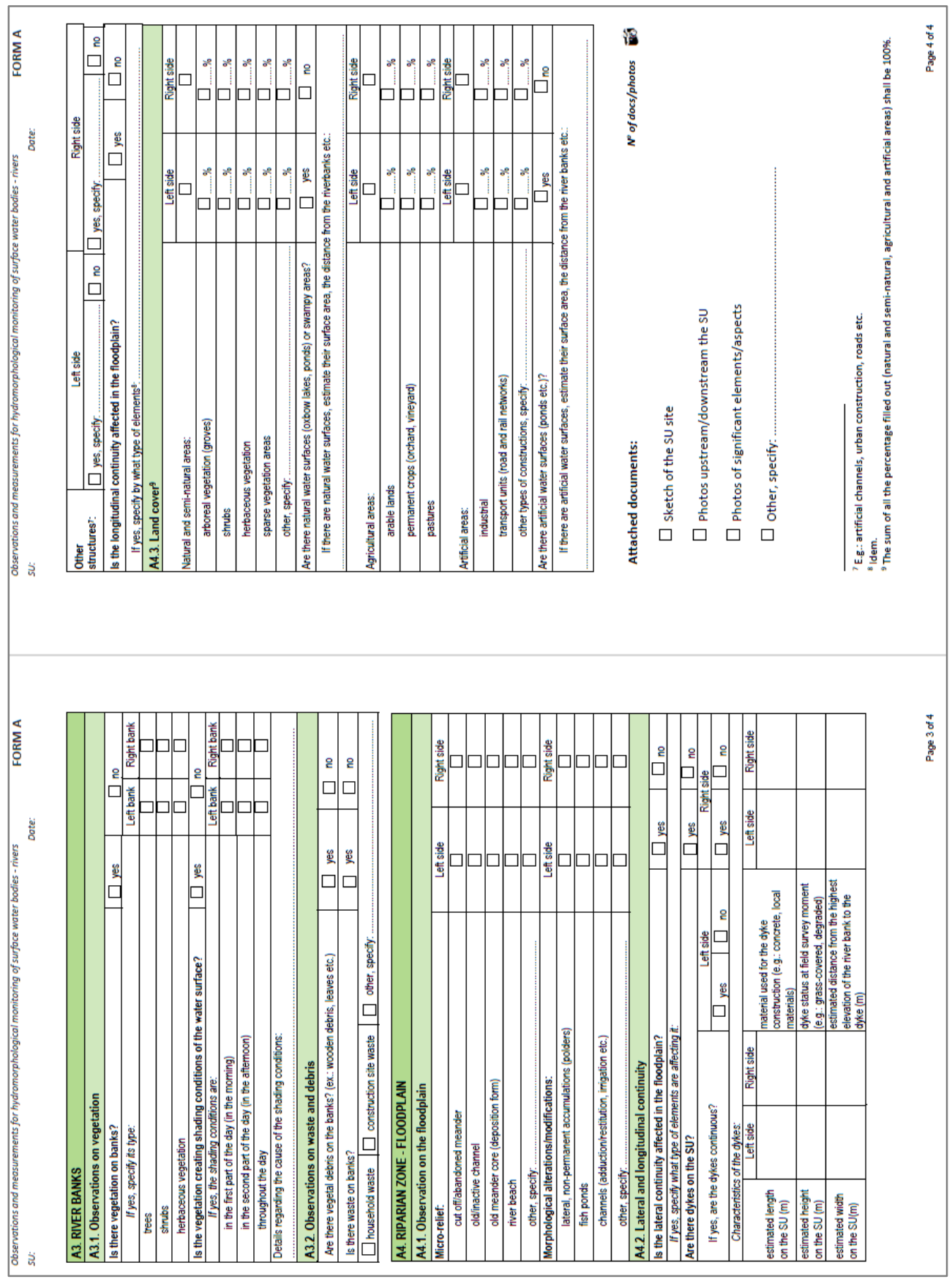

Fig. 2b. Form type A - Observations and measurements for hydromorpological monitoring of the surface water bodies - rivers through survey units, which refers to data collection on the survey unit on the whole - 500 m (pages 3-4) 


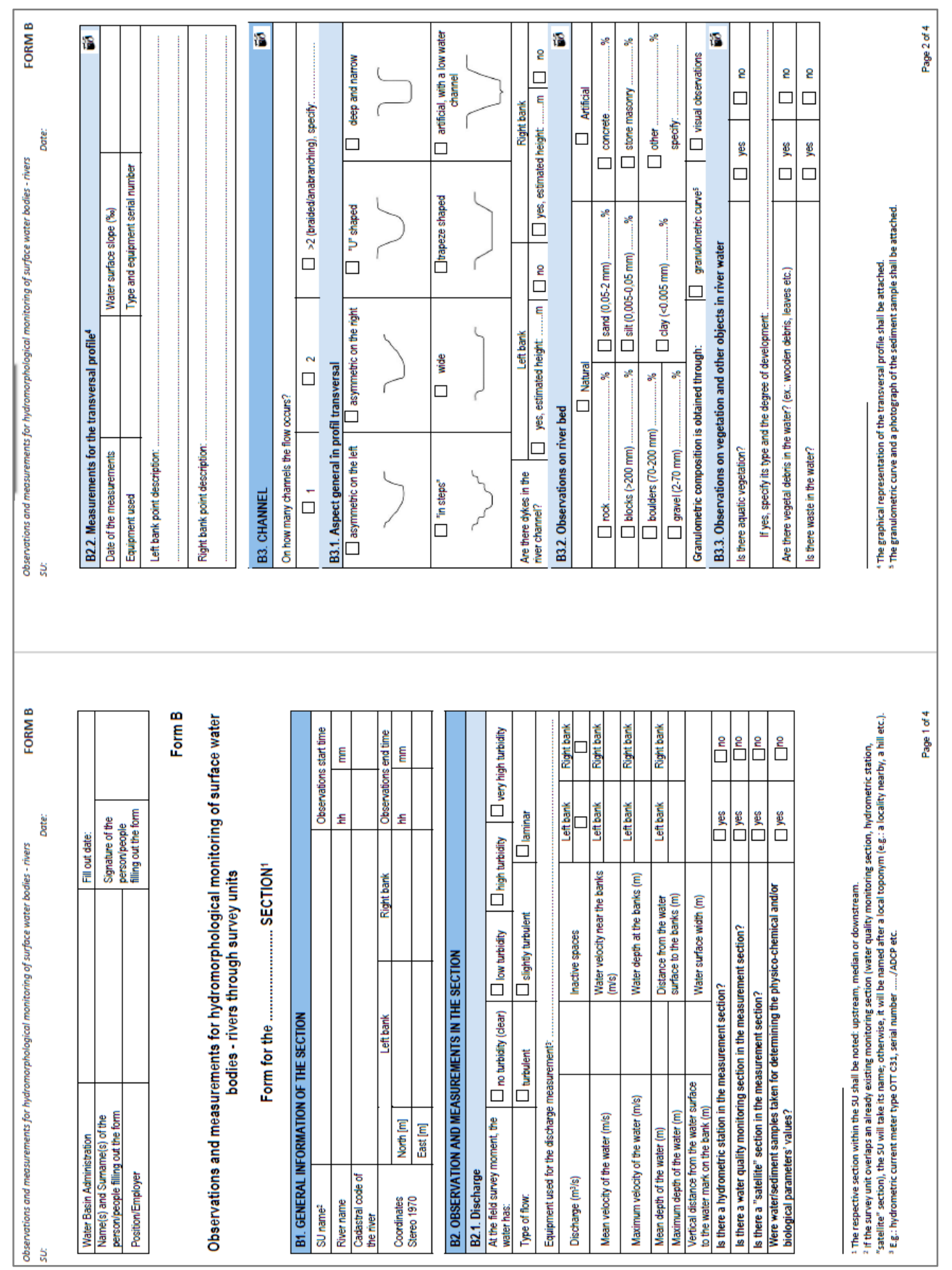

Fig. 3a. Form type B - Observations and measurements for hydromorpological monitoring of the surface water bodies - rivers through survey units, which refers to data collection on the survey sections (pages 1-2) 


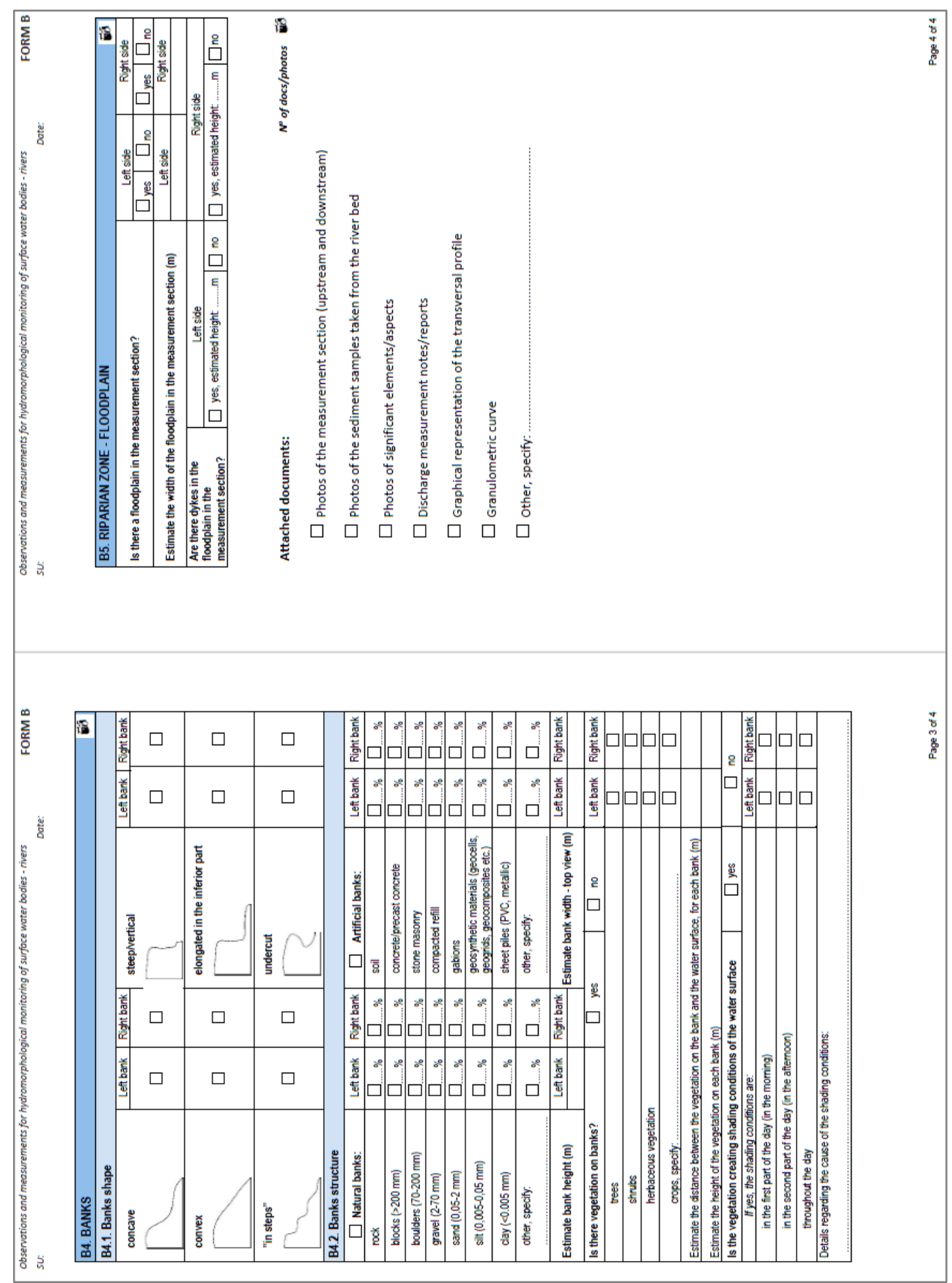

Fig. 3b. Form type B - Observations and measurements for hydromorpological monitoring of the surface water bodies - rivers through survey units, which refers to data collection on the survey sections (pages 3-4) 
This database, developed and updated in time, will support and guide the future research on river hydromorphology and a better understanding of the effects of hydromorphological changes on river biota.

\section{ACKNOWLEDGEMENTS}

The method to collect field data for hydromorphological monitoring of rivers in Romania is the result of research studies conducted by the National Institute of Hydrology and Water Management in 2016-2018. The "Romanian Waters" National Administration and the Water Basin Administrations provided support in testing the method on field, on river water bodies from all typologies.

\section{REFERENCES}

1. Administraţia Naţională "Apele Române” (ANAR) (2016), Planul Național de Management actualizat 2016-2021.

2. Birk S. (2003), Review of European assessment methods for rivers and streams using Benthic Invertebrates, Aquatic Flora, Fish and Hydromorphology, $\mathrm{PhD}$ Thesis, Universitatea Duisburg-Essen, Germania, $107 \mathrm{p}$.

3. Gurnell A. M., Rinaldi M., Belletti B., Bizzi S., Blamauer B., Braca G., Bujse A. D., Bussettini M., Camenen B., Comiti F., Demarchi L., Garcia de Jalon D., Gonzales del Tanago M., Grabowski R. C., Gunn I. D. M., Habersack H., Hendriks D., Henshaw A. J., Klosch M., Lastoria B., Latapie A., Marcinkowski P., Martinez-Fernandez V., Mosselman E., Mountford J. O., Nardi L., Okruszko T., O'Hare M. T., Palma M., Percopo C., Surian N., Van de Bund W., Weissteiner C., Zilliani L. (2016), A multi-scale hierarchical framework for developing understanding of river behaviour to support river management, Aquatic Sciences, 78, $1-16 \mathrm{p}$.

4. Ilnicki P., Górecki K., Grzybowski M., Krzemi A., Lewandowski P., Sojka M. (2010), Principles of hydromorphological surveys of Polish rivers, J. Water Land Dev. 14, 3-13 p.

5. Institutul Naţional de Hidrologie şi Gospodărire a Apelor (INHGA) (2015), Metodologie de determinare a indicatorilor hidromorfologici pentru cursurile de apă din România.

6. Institutul Național de Hidrologie și Gospodărire a Apelor (INHGA) (2016), Ghid privind determinarea parametrilor hidrologici și morfologici pentru râuri în conformitate cu Anexa V actualizată a Directivei Cadru Apă 2000/60/EC.

7. Lupu I., Moldoveanu M., Perju R., Gălie A. C. (2017), An approach for hydromorphological monitoring of river water bodies, Air and Water Components of the Environment, Edit. Casa Cărții de Știință, Cluj-Napoca, ISSN: 2067-743X, 18-25 p.

8. Moldoveanu M., Galie A., Rădulescu D. (2015), Methodology for hydromorphological assessment of Romanian rivers - Results of testing, 15th International Multidisciplinary Scientific Geoconference 2015, Albena, Conference Proceedings, ISBN 978-619-7105-36-0 / ISSN 1314-2704, Book 3 Vol. 1, p. 427-436. 
9. Wolter C., Lorenz S., Scheunig S., Lehmann N., Schomaker C., Nastase A., Diego García de Jalón D., Marzin A., Lorenz A., Kraková M., Brabec K., Noble R., (2013), Review on ecological response to hydromorphological degradation and restoration, REFORM Project (Restoring Rivers for Effective Catchment Management).

10. *** (2005), Water quality - Guidance standard for assessing the hydromorphological features of rivers, SR EN 14614/2005.

11. *** (2010), Water quality - Guidance standard on determining the degree of modification of river hydromorphology, EN 14614/2010.

12. *** (2014), Directiva 2014/60/UE a Comisiei din 30 octombrie 2014 de modificare a Directivei 2000/60/CE, Parlamentul European și Comisia de stabilire a unui cadru de politică comunitară în domeniul apei. 